\title{
FISCAL IMPULSE AND SECTORAL OUTPUT - EVIDENCE FROM INDIAN STATES
}

\author{
GAUTAM NEGI
}

\begin{abstract}
The study covering the states of India for the period 2005 up to 2020 examines the growth effect of fiscal impulse on sectoral output. Gross value added of sectors is taken as the dependent variable while fiscal impulse as a ratio of the state domestic product has been taken as the explanatory variable. Four control variables are additional included. The study employs the generalized method of moments (GMM) for estimation. For industry and the services sector, growth effect of fiscal impulse is found to be positive and significant while for agriculture sector the effect is not significant. A sample split of states reveal developed states to be benefitting more from the growth effect of fiscal impulse as compared to the lesser developed states. The study contributes to the literature on fiscal policy and growth among the states of India.
\end{abstract}

Keywords: fiscal impulse, output, growth, GMM.

JEL Classification: $E 620$

\section{INTRODUCTION}

Globally, fiscal and the monetary policy are the principal policy measures adopted by economies for inducing growth (Arestis, 2012; Boskin, 2012a; Czasonis et al., 2020; Day \& Yang, 2010a). As regards the monetary policy, there is a broad consensus on the impact of money supply and interest rates on stimulating credit growth and achieving the monetary policy objective of price stabilization (Goryunov \& Trunin, 2016; Johnson et al., 2000; Svensson, 1999; Wen, 2009). However, the economic view of the growth effect of fiscal policy has varied with time and among economists based on theory and empirical findings. The Keynesian approach which was effective in reviving the economic growth during the great depression of 1929

\footnotetext{
${ }^{i}$ Lal Bahadur shastri Institute of Management, Delhi, India, Postal Address - Plot No. 11/7, Sector 11, Dwarka, New Delhi -110075, E mail address: gautamnegi008@gmail.com
} 
advocates increased government spending or an expansionary fiscal policy to spur consumption demand. This theory is based on the premise that the fiscal deficit primarily accounted for by government spending and especially in the infrastructure sector facilitates private investment and due to the "crowding in" effect it fosters growth (Amiri, 2013; Marimuthu et al., 2021a). A few empirical studies supporting the Keynesian thought of increased capital accumulation due to increase in fiscal deficit include Auerbach (2012), Fazzari (1994), Fontana (2009) and Musgrave (1987). The neo classical approach believes that an increase in fiscal deficit increases consumption levels but reduces savings thereby increasing interest rates (Canova \& Pappa, 2011, Kumar. R \& Soumya, 2010; McCallum, 2005). This results in suppressing economic activity. This thought is based on the premise that the fiscal deficits driven by government expenditure have a "crowding out" effect on private investment. It implies higher productive capital replaced by relatively lesser efficient government investment. The third view referred to as the "Ricardian approach" argues the impact of fiscal deficit to be neutral. But, based on empirical findings, this theory has received little or insignificant support from economists and policy makers (Doi, 2018; Mankiw, 2010). Thus, the Keynesian and the neo classical approaches can be viewed as two competing theories in the context of the relationship between fiscal deficit and growth.

The fiscal policy primarily revolves around government expenditure, taxes, and investment (Spilimbergo et al., 2009; Tanzi, 1993). The taxes form sources of revenue while the government expenditure and investment contribute to the expenses. The difference between the revenues and expenses can be surplus or deficit. A large deficit is generally met by drawings from the foreign exchange reserves or borrowings from the domestic or foreign markets. The excess foreign exchange drawings lead to balance of payments difficulties, the foreign borrowings lead to increased future debt obligations while the domestic borrowings tend to push the interest rates higher (Kumar S, 2012; Singh \& Srinivasan, 2004). There is consensus that controlling fiscal deficit will enable economies to develop in the long run (Kleis, 2016; Marimuthu et al., 2021a; Petrovic \& Brcerevic, 2014; Sen \& Kaya, 2017). It has also been argued that the effectiveness of the fiscal policy including policy multiplier may vary with respect to economic conditions (Day \& Yang, 2010b). Fiscal policy may be more effective in recessions (Goolsbee, 1998).

For developing economies government expenditure in social and infrastructure related projects may often lead to large fiscal deficits. For these economies it is important to balance their government finances with investments in the social and capital-intensive sectors (Koreh \& Béland, 2017; Sinfield, 2020). 
There are numerous studies available examining the relationship between fiscal policy and growth especially in the developed and advanced economies including Dekel (1994), Jaramillo \& Cottarelli (2012) and Pasichnyi (2017). Although literature seems to suggest that the growth effect of fiscal deficit has mixed results depending on stage of economic development and expenditure composition, fiscal consolidation continues to be one of the major macroeconomic policy areas for all economies.

Literature on growth effect of fiscal policy at sector level are scarce. A few studies on growth effect of fiscal policy at country level include Isiaq (2013) for Nigeria, Tagkalakis (2013) for Greece, Gavin \& Perotti (1997) for Latin America and Hussain \& Haque (2017) for Bangladesh.

In the context of India, Raja Chelliah was one of the chief architects of India's public finance policies. He proposed increased compulsory savings through taxation coupled with high public and private investment as conducive for economic growth (Prest \& Chelliah, 1960). This view over the years has been supported by many researchers including the recent studies of Medhi (2014), Mishra \& Mohanty (2021) and Sharma \& Sharma (2014). For India, to the author's best knowledge, studies on the sectoral impact on output of fiscal policy at country and state level are at best scarce. The present study attempts to fill this gap. The remaining part of the paper is organized as follows- section 2 covers prior work on the nexus between fiscal policy and growth, section 3 details the data and methodology used, section 4 discusses and reports the empirical findings of the study while conclusion is presented in section 5 .

\section{LITERATURE REVIEW}

Literature related to fiscal policy differentiates between fiscal expansion and fiscal adjustment (Perrotti,1998). While the former is achieved through increased expenditure the latter relies on tax increases. Broadly, the studies on fiscal policy can be segmented as those examining (i) growth effects of fiscal policy at country/region level; (ii) growth effects of select fiscal policy variables; or (iii) the impact of fiscal policy on development indicators.

\subsection{Country/region level studies}

Most studies on the growth effect of fiscal policy are focused on developed and advanced economies including recent studies by Iorio \& Fachin (2021), Leeper \& Walker (2011) and Ubide (2016). One of the earliest studies covering underdeveloped countries was by Prest \& Chelliah (1960). Other prominent works 
include Perotti (2004) based on OECD countries, Ridzuan \& Abd Rahman (2021) and Tang et al (2013) on ASEAN countries. In their study on developing economies Adam \& Bevan (2005) estimate that the long-term growth dividend of cutting the deficit disappears or reverses below a threshold of around $1 \frac{1}{2}$ percent of GDP. An emerging market economies study by Fetai (2017) finds the effective role of fiscal policy in shortening the duration of financial crises.

The procyclical nature of the fiscal policy has also been examined in a few studies. The fiscal policy is procyclical in advanced/resource rich economies as observed by Aliyev (2012). The fiscal policy for developing economies is generally procyclical with spending increases (tax reductions) during boom and spending reductions (tax increases) during recessionary periods (Alesina A.F \& Tabellini, 2005).

\subsection{Growth effect of select fiscal policy variables}

The common fiscal policy variables include public spending, taxation, and public debt. Most studies confirm public spending raises economic growth (Bayraktar \& Moreno-Dodson, 2012; Greiner, 2015a). Different allocations of public resources lead to different growth rates (Paternostro et al., 2012). A recent study of 19 Asian countries by Gnangoin et al (2019) for the period 2002- 2017 finds public spending to have a positive impact on growth. In a study of developed economies Boris (2014) and Greiner (2015b) find public debt to hamper growth. In a recent study covering developing economies. Megersa \& Cassimon (2015) find a significant negative relationship between public debt and growth. Cecchetti et al (2010a) in their study on industrialized economies with large aging population find the debt/GDP ratios to be unsustainable in the future. Gupta et al (2004) finds increasing efficiency of the tax system or enhanced spending on the infrastructure to push up the per capita growth. Further, broadening tax base supports growth for these economies. Alesina A.F. \& Ardagna (2009) argue that fiscal consolidation based on tax increases is short lived fiscal consolidation based on cutting public employment and government wages is likely to have a long-term effect. Over a longer period, tax cuts as compared to increased government expenditure is likely to have a more favorable growth effect (Alesina A.F \& Tabellini, 2005 b).

\subsection{Fiscal policy and development indicators}

Lustig (2016) in a study of 25 developing nations find fiscal policy to always reduce inequality but has mixed results on the poverty reduction. In a study of OECD countries covering the last four decades Salotti \& Trecroci (2013) finds that 
the increase in government debt and expenditure promote a less unequal distribution of income.

\section{Data ANd Methodology}

The study has two objectives. First is a state level examination of the growth effect of fiscal impulse on GVA of different sectors of the state economy. Second is to examine whether there is a variation in the growth effect if states are classified based on per capita income.

\subsection{Measuring fiscal impulse}

At a macro level and especially for developing economies, fiscal policy plays an important role in inducing domestic demand through enhanced government expenditure. Worldwide a variety of indicators are used to assess the fiscal policy stance of any government. Currently two of the important indicators estimated by IMF at a country level to assess the fiscal stance include cyclically adjusted balances $(\mathrm{CAB})$ and structural balance $(\mathrm{SB})$. The CAB adjusts for the cyclical nature of revenues and expenses while SB further adjusts for additional items not closely related to the business cycle.

In the Indian context, state level fiscal indicators estimated by the Reserve Bank of India (RBI) include gross fiscal deficit (GFD), primary deficit (PFD), revenue deficit $(\mathrm{RD})$ and primary revenue deficit $(\mathrm{PRD})$ as depicted in Table 1

Table 1 List of fiscal indicators reported by RBI

\begin{tabular}{lll}
\hline S. No. & Indicator & Description \\
\hline 1 & Gross fiscal deficit & $\begin{array}{l}\text { Aggregate expenditure - Revenue receipts and non- } \\
\text { debt capital receipts }\end{array}$ \\
2 & Primary deficit & GFD - interest payments \\
3 & Revenue deficit & Revenue expenditure - revenue receipts \\
4 & Primary revenue deficit & Revenue deficit- interest payments \\
\hline
\end{tabular}

Conceptually, fiscal stimulus or fiscal impulse is measured as the change in the government budget balance (Schinasi \& Lutz, 1991). This could result from changes in the government expenditure or tax policies. One way of assessing the fiscal stance of the government is to look at the changes in one/more fiscal policy variables. The current study takes fiscal stimulus or fiscal impulse since it gives a composite view of the revenue and expenditure position of the government. 
Thus, the study uses primary deficit and its increase/decrease over time to give an indication of the fiscal stance of the government. If $P D_{t}$ and $P D_{t-1}$ are the primary deficits at two time periods, then the difference between the two gives an indication of the fiscal impulse (FI) in the year. Thus, $F I=P D_{t}-P D_{t-1}$.

A positive FI would indicate an accommodative stance or the fiscal stance getting more expansionary while a negative FI would be an indication of contraction of the fiscal stimulus.

\subsection{Selection of variables}

The study attempts to examine the impact of fiscal impulse on different sectors of the economy. Three sectors namely Agriculture, Industry and Services are considered in the study and the gross value added (GVA) of each sector has been taken as the dependent variable. Fiscal impulse as a ratio of the SDP of the state has been taken as the explanatory variable. Other control variables included in the model are credit extended by scheduled commercial banks, gross fixed capital formation, state domestic product and number of workers. The description of the variables is given in Table 2 .

Table 2 Description of the variables taken in the study

\begin{tabular}{lll}
\hline S. No. & Variables & Description \\
\hline 1 & GVAAGR & Natural logarithm of gross value added of the agriculture sector \\
2 & GVAIND & Natural logarithm of gross value added of the industry sector \\
3 & GVASER & Natural logarithm of gross value added of the services sector \\
4 & FI & Ratio of fiscal impulse and SDP of the state \\
5 & BCRDT & Natural logarithm of credit extended by scheduled commercial \\
& & banks \\
6 & GFCF & Natural logarithm of gross fixed capital formation \\
7 & SDP & Natural logarithm of state domestic product \\
8 & WRKRS & Natural logarithm of number of workers \\
\hline
\end{tabular}

\subsection{Data sources and sample selection}

The state level data for the study is sourced from Reserve Bank of India (RBI) data base available on its website. The figures of GVA for all sectors has been taken at constant prices with base year 2004-05. The RBI website has data available from 2004-05 onwards and hence the study period is from 2004-05 up to 2019-20. The study covers 26 of the 29 states of India. Data for Telangana state is available from 2014-15 onwards and hence dropped. Similarly due to unavailability of complete data for Arunachal Pradesh and Mizoram, these two 
have also been dropped from the sample. For the year 2019-20, these 3 states accounted for only 4.5 percent of the national gross domestic product and thus their omission from the study is unlikely to have any significant impact on the findings of the study.

\subsection{Summary statistics}

The summary statistics of the selected variables is presented in Table 3 .

Table 3 Summary Statistics

\begin{tabular}{llllll}
\hline Variables & No. of observations & Max & Min & Mean & STDEV \\
\hline GVAAGR & 390 & 122566 & 298 & 24249 & 23385 \\
GVAIND & 390 & 375135 & 561 & 56403 & 65913 \\
GVASER & 390 & 885374 & 1013 & 109209 & 132753 \\
FI & 390 & 42525 & -44038 & 422.27 & 6129 \\
BCRDT & 390 & 2450000 & 300 & 159862 & 327031 \\
GFCF & 390 & 99649 & 0.21 & 10564 & 14987 \\
SDP & 390 & 1060000 & 1036 & 158070 & 185583 \\
WRKRS & 390 & 2234321 & 1734 & 369297 & 4331 \\
\hline
\end{tabular}

(WRKRS is denoted in number of people while the unit of all other variables is in Rs. Cr)

Table 3 presents the summary statistics of the sample states in terms of output by economic activity (agriculture, industry, and services), state support through government expenditure (FI) and other economic and development indicators like bank credit, capital formation, SDP, and number of workers. The significant difference between the maximum and the minimum of the variables reflects the wide variations among the states in terms of population and stage of development. The mean of the fiscal impulse for the period is Rs.422.27 $\mathrm{Cr}$ indicating an overall expansionary stance of the fiscal policy adopted by states. 


\section{EMPIRICAL ANALYSIS, DisCUSSION AND FINDINGS}

\subsection{Estimation procedure}

On the available panel data, it is possible to employ the ordinary least squares or the fixed effects model for estimation. The following equation 1 is used to examine the relationship between GVA of the sectors and fiscal impulse.

$$
\ln G V A_{\text {pit }}=\alpha_{0}+\beta_{1} F I_{i t}+\gamma Z_{i t}+\epsilon_{i t}
$$

where $\ln G V A$ is the natural logarithm of gross value added, p represents output from agriculture, industry, and services. $F I_{i t}$ is the fiscal impulse of the $i^{\text {th }}$ state in the $\mathrm{t}^{\text {th }}$ year. $Z$ is the vector of the control variables that are believed to have an impact on GVA. The estimated result from eq. (1) is reported in table 4

Table 4 Estimation of relationship between output by economic activity and fiscal impulse

\begin{tabular}{|c|c|c|c|c|c|c|}
\hline & \multicolumn{3}{|c|}{ Ordinary least squares (OLS) } & \multicolumn{3}{|c|}{ Panel fixed effects (FE) } \\
\hline & 1 & 2 & 3 & 4 & 5 & 6 \\
\hline & GVAGR & GVAIND & GVASER & GVAAGR & GVAIND & GVASER \\
\hline FI & $\begin{array}{l}0.034 \\
(0.81)\end{array}$ & $\begin{array}{l}0.005 \\
(0.83)\end{array}$ & $\begin{array}{l}-0.005 \\
(0.81)\end{array}$ & $\begin{array}{l}-0.0008 \\
(0.93)\end{array}$ & \begin{tabular}{|l|}
.004 \\
$(0.54)$
\end{tabular} & $\begin{array}{l}-0.006 \\
(0.22)\end{array}$ \\
\hline BCRDT & $\begin{array}{l}0.37^{* * * *} \\
(0.000)\end{array}$ & $\begin{array}{l}0.25^{* * *} \\
(0.000)\end{array}$ & $\begin{array}{l}0.57^{* * *} \\
(0.000)\end{array}$ & $\begin{array}{l}0.09^{* *} \\
(0.06)\end{array}$ & $\begin{array}{l}0.93^{* * *} \\
(0.000)\end{array}$ & $\begin{array}{l}0.09^{* * * *} \\
(0.000)\end{array}$ \\
\hline GFCF & $\begin{array}{l}0.08^{* * * *} \\
0.0000\end{array}$ & $\begin{array}{l}0.08^{* * *} \\
(0.000)\end{array}$ & $\begin{array}{l}-0.07^{* * * *} \\
(0.000)\end{array}$ & $\begin{array}{l}0.019^{* *} \\
(0.08)\end{array}$ & $\begin{array}{l}0.014^{* *} \\
(0.04)\end{array}$ & $\begin{array}{l}0.005 \\
(0.38)\end{array}$ \\
\hline SDP & $\begin{array}{l}0.13^{* * *} \\
(0.000)\end{array}$ & $\begin{array}{l}0.17^{* * * *} \\
(0.000)\end{array}$ & $\begin{array}{l}0.14^{* * *} \\
(0.000)\end{array}$ & $\begin{array}{l}0.22^{* * * *} \\
(0.000)\end{array}$ & $\begin{array}{l}1.04^{* * *} \\
(0.000)\end{array}$ & $\begin{array}{l}0.107^{* * * *} \\
(0.000)\end{array}$ \\
\hline WRKRS & $\begin{array}{l}0.39^{* * * *} \\
(0.000)\end{array}$ & $\begin{array}{l}0.29^{* * * *} \\
(0.000)\end{array}$ & $\begin{array}{l}0.21^{* * *} \\
(0.000)\end{array}$ & $\begin{array}{l}0.08^{* * * *} \\
(0.000)\end{array}$ & $\begin{array}{l}0.07^{* * *} \\
(0.000)\end{array}$ & $\begin{array}{l}0.004 \\
(0.81)\end{array}$ \\
\hline R Square & 0.79 & 0.96 & 0.96 & 0.99 & 0.98 & 0.99 \\
\hline $\mathrm{N}$ & 390 & 390 & 390 & 390 & 390 & 390 \\
\hline
\end{tabular}

Note: GVAGR, GVAIND and GVASER are the dependent variable in each of the specified models. Figures in parenthesis are the respective $\mathrm{p}$ values. $* * *, * *, *$ denotes values significant at $1 \%$, $5 \%$ and $10 \%$ confidence levels respectively.

It can be observed from table 4 that the impact of fiscal impulse on output is insignificant for all models. However, all other variables have a positive and significant impact on output irrespective of the model specification except for GFCF and WRKRS in model 6. 
The panel data estimation using the fixed effects helps in eliminating the state specific fixed effects. However, two visible problems remain. One is the problem of endogeneity due to the existence of a simultaneous relationship between the dependent and the independent variables. Secondly, the finite sample size is a limitation. The dataset consists of a wide panel of 26 states as cross sections but a relatively shorter time of 13 years. To address these issues, estimation is done using the generalized methods of moments (GMM). Model specification of GMM is as per eq (2). This is a minor modification of eq (1) with one lagged value of the output being taken as an explanatory variable in the model. Other notations are the same as in eq (1)

$$
\ln G V A_{\text {pit }}=\alpha_{0}+\beta_{0} \operatorname{lnGVA} A_{p i, t-1}+\beta_{1} F I_{i t}+\gamma Z_{i t}+\epsilon_{i t}
$$

The equation is estimated using one step GMM. The lagged values of the dependent and the independent variables are taken as instruments in the model. For testing the robustness of the model, two specification tests as proposed by Arellano \& Bond (1991) are used. The validity of the instruments is checked by the Sargan test, and the error terms are tested for no serial correlation.

The results of eq (2) are presented in table 5

Table 5 Estimation of relationship between output by economic activity and fiscal impulse using one step generalized method of moments

\begin{tabular}{|l|l|l|l|}
\hline & GVAAGR & GVAIND & GVASER \\
\hline GVAAGR $_{t-1}$ & $\begin{array}{l}\text { (.079** } \\
(0.091)\end{array}$ & & \\
\hline GVAIND $_{t-1}$ & & $\begin{array}{l}0.19185^{* * *} \\
(0.000)\end{array}$ & \\
\hline GVASER & & & \\
& & & 0.2309 \\
& & $0.137)$ \\
\hline FI & -0.0009 & $0.0045^{* * *}$ & $-0.0032^{* * *}$ \\
& $(0.651)$ & $(0.0001)$ & $(0.000)$ \\
\hline BCRDT & $0.1012^{* *}$ & 0.3909 & 0.2527 \\
& $(0.059)$ & $(0.1011)$ & $(0.1480)$ \\
\hline GFCF & $-0.0143^{* * *}$ & $0.0086^{* * *}$ & 0.0041 \\
& $(0.031)$ & $(0.0221)$ & $0.5551)$ \\
\hline SDP & $0.265^{* * *}$ & $1.585^{* * *}$ & $0.2158^{* * *}$ \\
& $(0.0282)$ & $(0.000)$ & $(0.000)$ \\
\hline WRKRS & 0.044 & $0.0586^{* * *}$ & 0.0079 \\
& $(0.345)$ & $(0.000)$ & $0.681)$ \\
\hline AR (1) & 0.000 & 0.000 & 0.000 \\
\hline AR $(2)$ & 0.341 & 0.313 & 0.271 \\
\hline
\end{tabular}




\begin{tabular}{|l|l|l|l|}
\hline & GVAAGR & GVAIND & GVASER \\
\hline Hansen test $(\mathrm{p}$ value) & & & \\
\hline $\mathrm{N}$ & 338 & 338 & 338 \\
\hline
\end{tabular}

Note: GVAGR, GVAIND and GVASER are the dependent variable in each of the specified models. Figures in parenthesis are the respective $\mathrm{p}$ values. $* * *, * *, *$ denotes values significant at $1 \%$, $5 \%$ and $10 \%$ confidence levels respectively.

The impact of fiscal impulse on the output of industry and services is positive and statistically significant. Thus, an expansionary stance of the fiscal policy seems to have a positive influence on both these sectors. However, the results seem to suggest that any change in fiscal impulse does not have any impact on agriculture output at state level. Most probable reason could be that agriculture output in India is still largely influenced by monsoons and other support subsidies/incentives from both the state and central governments. Among the other explanatory variables, the SDP has a positive and statistically significant impact on the output of all sectors with industry output increasing the maximum for every unit increase in the fiscal impulse. The results indicate that at state level gross capital formation does not impact output of any of the sectors. Number of workers has a significant impact on the industry output.

\subsection{Sample splits}

The states in India vary widely in terms of size and economic development. The impact of fiscal impulse can vary across states depending on the efficiencies in the utilization of the factors of production. Advanced states are more developed generally because of their efficiencies in utilizing factors of production. The study classifies states into 3 categories based on their average per capita income from the year 2010 to 2020. Category A is the group of states with the highest average per capita income while Category $\mathrm{C}$ are the states with the lowest average per capita income. These states as categorized are as per table 6 .

Table 6 Categorization of states on per capita income

\begin{tabular}{ccl}
\hline Category & No. of states & States \\
\hline A & 10 & $\begin{array}{l}\text { Goa, Gujrat, Haryana, Himachal Pradesh, Karnataka, Kerela, } \\
\text { Maharashtra, Sikkim, Tamil Nadu, Uttarakhand }\end{array}$ \\
\hline B & 8 & $\begin{array}{l}\text { Andhra Pradesh, Chhattisgarh, Nagaland, Odisha, Punjab, } \\
\text { Rajasthan, Tripura, West Bengal }\end{array}$ \\
\hline C & 8 & $\begin{array}{l}\text { Assam, Bihar, Jammu and Kashmir, Jharkhand, Madhya } \\
\text { Pradesh, Manipur, Meghalaya, Uttar Pradesh }\end{array}$ \\
\hline
\end{tabular}


The impact of the fiscal impulse on the output by economic activity for each of these categories is examined. Since the cross sections are now reduced with the time of study remaining the same, panel data model can be appropriately applied. The random effects model is first run on each of the models. Hausman test with the null hypothesis that the random effects model is appropriate for the data is used to determine the choice between the random effects or the fixed effects model for the data. Results are reported in table 7

Table 7 Panel data estimation results of sample splits

\begin{tabular}{|l|l|l|l|l|l|l|l|l|l|}
\hline & \multicolumn{3}{|c|}{ Cat A } & \multicolumn{3}{c|}{ Cat B } & \multicolumn{3}{|c|}{ Cat C } \\
\hline & $\mathrm{A}^{*}$ & $\mathrm{I}^{*}$ & $\mathrm{~S}^{*}$ & $\mathrm{~A}^{*}$ & $\mathrm{I}^{*}$ & $\mathrm{~S}^{*}$ & $\mathrm{~A}^{*}$ & $\mathrm{I}^{*}$ & $\mathrm{~S}^{*}$ \\
\hline FI & $\mathrm{FE}$ & $\mathrm{FE}$ & $\mathrm{FE}$ & $\mathrm{FE}$ & $\mathrm{FE}$ & $\mathrm{FE}$ & $\mathrm{RE}$ & $\mathrm{FE}$ & $\mathrm{RE}$ \\
& -0.54 & $0.16^{* * * *}$ & -0.04 & -0.02 & $0.001^{* *}$ & -0.009 & 0.003 & -0.23 & $0.05^{* * *}$ \\
& 0.13 & 0.042 & 0.87 & 0.75 & 0.07 & 0.114 & 0.98 & 0.87 & 0.00 \\
\hline BCRDT & $-0.13^{* * *}$ & $0.26^{* * *}$ & $0.29^{* * * *}$ & $3.69^{* * *}$ & $0.004^{* *}$ & $0.21^{* * *}$ & 0.04 & $-0.15^{* * * *}$ & $0.39^{* * * *}$ \\
& .00 & 0.00 & 0.00 & 0.00 & 0.08 & 0.00 & 0.31 & 0.004 & 0.00 \\
& & & & & & & & & \\
\hline GFCF & 0.01 & $0.013^{* * * *}$ & -0.01 & 2.58 & $0.012^{* * * *}$ & 0.021 & 0.02 & $0.05^{* * * *}$ & $-0.03^{* * * *}$ \\
& 0.19 & 0.018 & 0.18 & 0.01 & 0.023 & 0.26 & 0.127 & 0.003 & 0.03 \\
\hline SDP & $0.44^{* * * *}$ & $1.63^{* * *}$ & $1.63^{* * * *}$ & $1.99^{* * *}$ & $1.07^{* * *}$ & $0.94^{* * *}$ & $0.93^{* * *}$ & $1.79^{* * *}$ & $0.32^{* * * *}$ \\
& 0.00 & 0.00 & 0.00 & 0.003 & 0.00 & 0.00 & 0.00 & 0.00 & 0.00 \\
\hline WRKRS & $0.21^{* * * *}$ & $0.13^{* * * *}$ & $0.13^{* * * *}$ & 0.05 & $0.027^{* *}$ & 0.03 & 0.06 & $-0.18^{* * *}$ & $0.24^{* * *}$ \\
& 0.00 & 0.00 & 0.00 & 0.17 & 0.042 & 0.34 & 0.19 & 0.05 & 0.00 \\
\hline $\mathrm{N}$ & 150 & 150 & 150 & 120 & 120 & 120 & 120 & 120 & 120 \\
\hline $\begin{array}{l}\text { Hausman test chi } \\
\text { square p value }\end{array}$ & 0.0065 & 0.00 & 0.02 & 0.00 & 0.00 & 0.00 & 0.00 & 0.334 & 0.96 \\
\hline
\end{tabular}

Note: $\mathrm{A}^{*}, \mathrm{I}^{*}$ and $\mathrm{S}^{*}$ denote gross value added by agriculture, industry, and services respectively. FE and RE represent fixed effects and random effects model respectively. Figures in parenthesis are the respective $\mathrm{p}$ values. $* * *, * * *$ denotes values significant at $1 \%, 5 \%$ and $10 \%$ confidence levels respectively.

It can be observed from table 7 that the impact of fiscal impulse on output of industry is positive and statistically significant for both category A and B states. Similarly, the impact of gross capital formation and number of workers is also positive and significant on the industry output. Being amongst the more developed states of India, these states are relatively better in the utilization of their resources. These states are better able to exploit the increased expenditure of the government whether capital or revenue. Bank credit also has a positive and significant impact on output of each of the sectors. The impact of SDP across the states is positive on the output of each of the sectors. The results indicate that the more developed states better utilize the fiscal impulse advantage as compared to the lesser developed 
states. However, the lesser developed states do well on exploiting the advantages from increase in gross capital formation.

\section{SUMMARY AND CONCLUSIONS}

Initial results of the OLS and FE model suggest that fiscal impulse has an insignificant impact on the output of different sectors. However, estimation based on the GMM method gives different findings. Given the nature of the dataset, findings based on this model are likely to be more reliable. The findings of the model indicate the growth effect of fiscal impulse to be positive and significant for the industry and services sector. Given the agriculture output to still be largely dependent on the vagaries of the monsoon, the growth effect of this sector to fiscal impulse is insignificant. Among the explanatory variables BCRDT, GFCF and WRKRS have a positive and significant impact on the GVAIND.

Amongst the more developed states, the impact of fiscal impulse is positive and significant for industry output. The findings suggest that stage of development of states influence their leveraging of fiscal impulse to enhance output. However, the less developed states better exploit the advantages from GFCF. 


\section{REFERENCES}

1. Adam, C. S., \& Bevan, D. L. (2005). Fiscal deficits and growth in developing countries. Journal of Public Economics, 89(4), 571-597. https://doi.org/10.1016/j.jpubeco.2004.02.006

2. Alesina, A., \& Ardagna, S. (1998). Tales of fiscal adjustment. Economic Policy, 13(27), 487-545. https://doi.org/10.1111/1468-0327.00039

3. Alesina, A. F., \& Ardagna, S. (2009). Large Changes in Fiscal Policy: Taxes Versus Spending. SSRN Electronic Journal. Published. https://doi.org/10.2139/ssrn.1502862

4. Alesina, A. F., \& Tabellini, G. (2005). Why is Fiscal Policy Often Procyclical? SSRN Electronic Journal. Published. https://doi.org/10.2139/ssrn.780225

5. Alesina, A. F., \& Tabellini, G. (2005 b). Why is Fiscal Policy Often Procyclical? SSRN Electronic Journal. Published. https://doi.org/10.2139/ssrn.780225

6. Aliyev, I. (2012). Is Fiscal Policy Procyclical in Resource-Rich Countries. SSRN Electronic Journal. Published. https://doi.org/10.2139/ssrn.2113937

7. Amiri, A. (2013). Does Government Expenditure Play an Efficient Role on Economic Growth? Evidence from Some OPEC Members. Journal of Macroeconomic Dynamics Research, 1(1), 1. https://doi.org/10.12966/jmdr.05.01.2013

8. Arellano, M., \& Bond, S. (1991). Some Tests of Specification for Panel Data: Monte Carlo Evidence and an Application to Employment Equations. The Review of Economic Studies, 58(2), 277. https://doi.org/10.2307/2297968

9. Arestis, P. (2012). Fiscal policy: a strong macroeconomic role. Review of Keynesian Economics, O(1), 93-108. https://doi.org/10.4337/roke.2012.01.06

10. Auerbach, A. J. (2012). The Fall and Rise of Keynesian Fiscal Policy. Asian Economic Policy Review, 7(2), 157-175. https://doi.org/10.1111/j.17483131.2012.01228.x

11. Bayraktar, N., \& Moreno-Dodson, B. (2012). HOW CAN PUBLIC SPENDING HELP YOU GROW? AN EMPIRICAL ANALYSIS FOR DEVELOPING COUNTRIES. Bulletin of Economic Research, 67(1), 30-64. https://doi.org/10.1111/j.1467-8586.2012.00473.x

12. Boris, G. (2014). Implications of public debt on economic growth and development. A European perspective. AESTIMATIO, 9(2014), 48-67. https://doi.org/10.5605/ieb.9.3

13. Boskin, M. J. (2012a). Fiscal Policy for Economic Growth. The Economists' Voice, 9(2). https://doi.org/10.1515/1553-3832.1898

14. Canova, F., \& Pappa, E. (2011). Fiscal policy, pricing frictions and monetary accommodation. Economic Policy, 26(68), 555-598. https://doi.org/10.1111/j.14680327.2011.00272.x

15. Cecchetti, S. G., Mohanty, M. S., \& Zampolli, F. (2010a). The Future of Public Debt: Prospects and Implications. SSRN Electronic Journal. Published. https://doi.org/10.2139/ssrn.1599421

16. Czasonis, M., Kritzman, M., \& Turkington, D. (2020). The Relative Importance of Fiscal and Monetary Policy: An Empirical Perspective. SSRN Electronic Journal. Published. https://doi.org/10.2139/ssrn.3595562

17. Day, R. H., \& Yang, C. (2010a). ECONOMIC GROWTH AND THE EFFECTS OF FISCAL POLICY. Metroeconomica, 62(1), 218-234. https://doi.org/10.1111/j.1467999x.2010.04108.x 
18. Day, R. H., \& Yang, C. (2010b). ECONOMIC GROWTH AND THE EFFECTS OF FISCAL POLICY. Metroeconomica, 62(1), 218-234. https://doi.org/10.1111/j.1467999x.2010.04108.x

19. Dekel, G. P. (1994). The fiscal impact of development. Land Use Policy, 11(2), 128 141. https://doi.org/10.1016/0264-8377(94)90007-8

20. Doi, T. (2018). Is Abe's Fiscal Policy Ricardian? What Does the Fiscal Theory of Prices Mean for Japan? Asian Economic Policy Review, 13(1), 46-63. https://doi.org/10.1111/aepr.12199

21. Fazzari, S. M. (1994). Why Doubt the Effectiveness of Keynesian Fiscal Policy?

Journal of Post Keynesian Economics, 17(2), 231-248. https://doi.org/10.1080/01603477.1994.11490025

22. Fetai, B. (2017). The effects of fiscal policy during the financial crises in transition and emerging countries: does fiscal policy matter? Economic Research-Ekonomska Istraživanja, 30(1), 1522-1535. https://doi.org/10.1080/1331677x.2017.1340181

23. Fontana, G. (2009). The transmission mechanism of fiscal policy: a critical assessment of current theories and empirical methodologies. Journal of Post Keynesian Economics, 31(4), 587-604. https://doi.org/10.2753/pke0160-3477310404

24. Gavin, M., \& Perotti, R. (1997). Fiscal Policy in Latin America. NBER Macroeconomics Annual, 12, 11-61. https://doi.org/10.1086/654320

25. Gnangoin, Du, Assamoi, Edjoukou, \& Kassi. (2019). Public Spending, Income Inequality and Economic Growth in Asian Countries: A Panel GMM Approach. Economies, 7(4), 115. https://doi.org/10.3390/economies7040115

26. Goolsbee, A. (1998). Fiscal Policy: Lessons from Economic Research. By ALAN AUERBACH. National Tax Journal, 51(2), 405-409.

https://doi.org/10.1086/ntj41789337

27. Goryunov, E., \& Trunin, P. (2016). The Main Areas of Monetary Policy: Price Stability, Resistance to Shocks. SSRN Electronic Journal. Published.

https://doi.org/10.2139/ssrn.2889462

28. Greiner, A. (2015a). Public Debt, Productive Public Spending and Endogenous

Growth. Japanese Economic Review, 66(4), 520-535.

https://doi.org/10.1111/jere.12077

29. Greiner, A. (2015b). Public Debt, Productive Public Spending and Endogenous Growth. Japanese Economic Review, 66(4), 520-535.

https://doi.org/10.1111/jere.12077

30. Gupta, S., Clements, B., Baldacci, E., \& Mulas-Granados, C. (2004). The persistence of fiscal adjustments in developing countries. Applied Economics Letters, 11(4), 209212. https://doi.org/10.1080/13504850410001674812

31. Hussain, M., \& Haque, M. (2017). Fiscal Deficit and Its Impact on Economic Growth: Evidence from Bangladesh. Economies, 5(4), 37.

https://doi.org/10.3390/economies5040037

32. Iorio, F. D., \& Fachin, S. (2021). Fiscal reaction functions for the advanced economies revisited. Empirical Economics. Published. https://doi.org/10.1007/s00181-02102119-y

33. Isiaq, I. O. (2013). Fiscal Policy and Sectoral Output in Nigeria. SSRN Electronic Journal. Published. https://doi.org/10.2139/ssrn.2338029 
34. Jaramillo, L., \& Cottarelli, C. (2012). Walking Hand in Hand: Fiscal Policy and Growth in Advanced Economies. IMF Working Papers, 12(137), 1. https://doi.org/10.5089/9781475503913.001

35. Johnson, K. H., Small, D. H., \& Tryon, R. W. (2000). Monetary Policy and Price Stability. SSRN Electronic Journal. Published. https://doi.org/10.2139/ssrn.231788

36. Kleis, M. (2016). The Long-Run Effect of Fiscal Consolidation on Economic Growth: Evidence from Quantitative Case Studies. SSRN Electronic Journal. Published. https://doi.org/10.2139/ssrn.2801590

37. Koreh, M., \& Béland, D. (2017). Reconsidering the fiscal-social policy nexus: the case of social insurance. Policy \& Politics, 45(2), 271-286. https://doi.org/10.1332/030557317x14860555458738

38. Kumar, R., \& Soumya, A. (2010). Fiscal Policy Issues for India after the Global Financial Crisis (2008-2010). SSRN Electronic Journal. Published. https://doi.org/10.2139/ssrn.1678419

39. Kumar, S. (2012). European Monetary System and the Fiscal Crisis. India Quarterly: A Journal of International Affairs, 68(2), 155-171. https://doi.org/10.1177/0974928412449247

40. Leeper, E. M., \& Walker, T. B. (2011). Fiscal Limits in Advanced Economies*. Economic Papers: A Journal of Applied Economics and Policy, 30(1), 33-47. https://doi.org/10.1111/j.1759-3441.2011.00111.x

41. Lustig, N. (2016). Fiscal Policy, Inequality and the Poor in the Developing World. SSRN Electronic Journal. Published. https://doi.org/10.2139/ssrn.2893758

42. Mankiw, N. G. (2010). Questions about Fiscal Policy: Implications from the Financial Crisis of 2008-2009. Review, 92(3). https://doi.org/10.20955/r.92.177-184

43. Marimuthu, M., Khan, H., \& Bangash, R. (2021a). Is the Fiscal Deficit of ASEAN Alarming? Evidence from Fiscal Deficit Consequences and Contribution towards Sustainable Economic Growth. Sustainability, 13(18), 10045. https://doi.org/10.3390/su131810045

44. Marimuthu, M., Khan, H., \& Bangash, R. (2021b). Is the Fiscal Deficit of ASEAN Alarming? Evidence from Fiscal Deficit Consequences and Contribution towards Sustainable Economic Growth. Sustainability, 13(18), 10045. https://doi.org/10.3390/su131810045

45. McCallum, B. T. (2005). Monetary and Fiscal Theories of the Price Level: The Irreconcilable Differences. Oxford Review of Economic Policy, 21(4), 565-583. https://doi.org/10.1093/oxrep/gri032

46. Medhi, K. (2014). An Empirical Investigation of the Causality between Government Expenditure and Economic Growth in India during 1974-2010. IOSR Journal of Humanities and Social Science, 19(7), 53-58. https://doi.org/10.9790/0837-19745358

47. Megersa, K., \& Cassimon, D. (2015). Public Debt, Economic Growth, and Public Sector Management in Developing Countries: Is There a Link? Public Administration and Development, 35(5), 329-346. https://doi.org/10.1002/pad.1733

48. Mishra, B. R., \& Mohanty, A. R. (2021). Nexus between government expenditure and economic growth: Evidence from sub-national governments in India. The Journal of Developing Areas, 55(2). https://doi.org/10.1353/jda.2021.0045

49. Musgrave, R. A. (1987). U.S. Fiscal Policy, Keynes, and Keynesian Economics. Journal of Post Keynesian Economics, 10(2), 171-182. https://doi.org/10.1080/01603477.1987.11489671 
50. Pasichnyi, M. (2017). Empirical study of the fiscal policy impact on economic growth. Problems and Perspectives in Management, 15(3), 316-322. https://doi.org/10.21511/ppm.15(3-2).2017.01

51. Paternostro, S., Rajaram, A., \& Tiongson, E. R. (2012). How Does the Composition of Public Spending Matter? A Framework Relating Public Spending to Growth, Equity and Poverty-Reduction Objectives. SSRN Electronic Journal. Published. https://doi.org/10.2139/ssrn.2028352

52. Perotti, R. (1998). The Political Economy of Fiscal Consolidations. Scandinavian Journal of Economics, 100(1), 367-394. https://doi.org/10.1111/1467-9442.00107

53. Perotti, R. (2004). Estimating the Effects of Fiscal Policy in OECD Countries. SSRN Electronic Journal. Published. https://doi.org/10.2139/ssrn.637189

54. Petrovic, P., \& Brcerevic, D. (2014). Fiscal consolidation: Precondition for growth. Ekonomika Preduzeca, 62(1-2), 21-34. https://doi.org/10.5937/ekopre1402021p

55. Prest, A. R., \& Chelliah, R. J. (1960). Fiscal Policy in Underdeveloped Countries. Economica, 27(108), 395. https://doi.org/10.2307/2550572

56. Prest, A. R., \& Chelliah, R. J. (1960b). Fiscal Policy in Underdeveloped Countries. Economica, 27(108), 395. https://doi.org/10.2307/2550572

57. Ridzuan, M. R., \& Abd Rahman, N. A. S. (2021). The Deployment of Fiscal Policy in Several ASEAN Countries in Dampening the Impact of COVID-19. Journal of Emerging Economies and Islamic Research, 9(1), 16. https://doi.org/10.24191/jeeir.v9i1.9156

58. Salotti, S., \& Trecroci, C. (2013). Can Fiscal Policy Mitigate Income Inequality and Poverty? SSRN Electronic Journal. Published. https://doi.org/10.2139/ssrn.2379441

59. Schinasi, G. J., \& Lutz, M. S. (1991). Fiscal Impulse. IMF Working Papers, 91(91), 1. https://doi.org/10.5089/9781451851441.001

60. ŞEN, H., \& KAYA, A. (2017). Is Fiscal Consolidation a New Anchor or a Fiscal Trap for Growth and Employment? A Theoretical and Empirical Literature Based Analysis. Sosyoekonomi. Published. https://doi.org/10.17233/sosyoekonomi.334410

61. Sharma, S. K., \& Sharma, B. (2014). Reflections on Monetary and Fiscal Policies and Economic Growth in India (RMFPEGI). International Journal of Trade, Economics and Finance, 5(6), 551-556. https://doi.org/10.7763/ijtef.2014.v5.431

62. Sinfield, A. (2020). Building Social Policies in Fiscal Welfare. Social Policy and Society, 19(3), 487-499. https://doi.org/10.1017/s147474642000010x

63. Singh, N., \& Srinivasan, T. N. (2004). Fiscal Policy in India: Lessons and Priorities. SSRN Electronic Journal. Published. https://doi.org/10.2139/ssrn.509062

64. Spilimbergo, A., Symansky, S., Cottarelli, C., \& Blanchard, O. (2009). Fiscal Policy for the Crisis. IMF Staff Position Notes, 2008(01), 1. https://doi.org/10.5089/9781589067981.004

65. Svensson, L. E. (1999). Price Stability as a Target for Monetary Policy: Defining and Maintaining Price Stability. SSRN Electronic Journal. Published. https://doi.org/10.2139/ssrn.174380

66. Tagkalakis, A. O. (2013). Discretionary fiscal policy and economic activity in Greece. Empirica, 41(4), 687-712. https://doi.org/10.1007/s10663-013-9232-0

67. Tang, H. C., Liu, P., \& Cheung, E. C. (2013). Changing impact of fiscal policy on selected ASEAN countries. Journal of Asian Economics, 24, 103-116. https://doi.org/10.1016/j.asieco.2012.07.003 
68. Tanzi, V. (1993). Fiscal Policy and the Economic Restructuring of Economies in Transition. IMF Working Papers, 93(22), i. https://doi.org/10.5089/9781451921205.001

69. Ubide, A. (2016). The Case for an Active Fiscal Policy in the Developed World. Business Economics, 51(3), 158-160. https://doi.org/10.1057/s11369-016-0006-0

70. Wen, Y. (2009). Can Monetary Policy Affect GDP Growth? Economic Synopses, 2009(21). https://doi.org/10.20955/es.2009.21 